AWEJ for Translation \& Literary Studies, Volume 4, Number2. May 2020

DOI: http://dx.doi.org/10.24093/awejtls/vol4no2.14

Pp.177-186

\title{
Multimodal Conflict Management in English Fictional Discourse
}

Iryna Sieriakova

Department of Foreign Languages, Faculty of Economics and Law, Kyiv National Linguistic University, Kyiv, Ukraine

\section{Olha Chernenko}

Department of Germanic and Finno-Ugrian Philology, Faculty of Germanic Philology, Kyiv National Linguistic University, Kyiv, Ukraine

\section{Oleksandr Muntian}

Department of the Russian Language and Literature, Faculty of Slavic Philology, Kyiv National Linguistic University, Kyiv, Ukraine

\begin{abstract}
Modern linguistic studies encompass a wide range of approaches for explaining language in use through the set of different semiotic resources. This paper discusses the use and informative significance of such funds in the framework of conflict studies in English fictional discourse. The phenomenon of conflict discourse multimodality, which combines several semiotic systems as particular modes of communication, helps to reveal the communicative and pragmatic value of verbal and nonverbal means of conflict settlement and resolution. The paper aims to determine how the nonverbal means of communication in conflict discourse influence the process of conflict interaction and what implications its interpretation has on conflict development and resolution. To achieve this, the study relies upon the analysis of semantic, formal, and functional peculiarities of nonverbal conflict-management mode in the structural organization of conflict fictional discourse. The analysis of nonverbal mode as a combination of different semiotic resources reveals that nonverbal conflict-management mode is represented by a specific set of patterns in English fictional discourse. Moreover, the process of conflict communication may be regulated nonverbally, governing, completing, strengthening, or resolving the conflict. The obtained results indicate that analysis of the nonverbal means in conflict fiction discourse with a focus on multimodal studies enables to get a true picture of the role of nonverbal conflict-management mode in the actual and potential realization of communicative strategies which in correlation with its pragmatic impact and some sociolinguistic features contribute to the influence on the process of conflict resolution and management.
\end{abstract}

Keywords: English fictional discourse, multimodal discourse analysis, nonverbal conflictmanagement mode, behavioral patterns, sensory modalities

Cite as: Sieriakova,I., Chernenko, O., \& Muntian, O. (2020). Multimodal Conflict Management in English Fictional Discourse. Arab World English Journal for Translation \& Literary Studies 4 (2) 177-186. DOI: http://dx.doi.org/10.24093/awejtls/vol4no2.14 
AWEJ for Translation \& Literary Studies Volume, 4 Number 2 May 2020

Multimodal Conflict Management in English Fictional

Sieriakova, Chernenko \&Muntian

\section{Introduction}

Multimodal discourse analysis as an interdisciplinary approach to the study of oral and written, literary, and digital, verbal, and nonverbal language use aims at revealing formal and functional characteristics of the language concerning its social context, pragmatic intention, as well as sociopsychological characteristics of a person. Conflict-management mode in English fictional discourse comprises both verbal and nonverbal resources used by the characters influencing the beginning, escalation, culmination, and resolution of conflict communicative process. As far as conflict communication is characterized by a high level of tension and emotivity, it determines the choice of nonverbal means of communication as a unique way of conflict management and resolution (Gamble \& Gamble, 2012; Hasan, 1996). Conflict discourse being a complex multidimensional, multimodal and multifunctional phenomenon that always exists in context brings to light the necessity to analyze its various aspects, such as social, situational, historical, cognitive, intertextual, linguistic, and extra-linguistic ones, in conjunction with nonverbal mode research as a particular way for the full interpretation of a speaker's communicative behavior in conflict situations in English fictional discourse (Królikowska, 2015).

Almost all human communication, including conflicts as the process of active disagreement between people with opposing opinions or principles, is intrinsically multimodal, conveying the messages by using more than one semiotic mode or channel of communication. According to Kress (2010) and O'Halloran (2004), multimodal discourse analysis comprises the study of language in combination with other resources, such as music, images, gesture, action, symbolism. Multimodal phenomenon is realized through analysis and description of different semiotic resources (modes) which integrate across sensory modalities (e.g., visual, tactile, auditory, kinetic) in multimodal events, texts, discourses. So, communications are conveyed through a definite channel, or medium, and the diversity of semiotic resources or modes serves as a means of communicating and interpreting the transmitted messages (Makaruk, 2015). Although verbal mode generally predominates in a given medium, namely in the fictional discourse, conflict communicative situations are always characterized by a high percentage of nonverbal messages, completing, strengthening, opposing, substituting, or emphasizing the verbal resource.

This paper investigates the designation of various nonverbal means such as gestures, mimics, facial expressions, and voice qualities, etc. of the character in conflict situations depicted in the fragments of English fictional discourse. The complex of these nonverbal cues viewed as nonverbal conflict-management mode reveals a particular semiotic resource represented in specific nonverbal behavioral patterns, specifying the development of conflict communicative process.

Due to the tasks of the given research, the following sections suggest the analysis of the pragmatic nature of conflict fiction discourse as well as the correlation between a verbal and nonverbal mode that contribute to better understanding of the role of nonverbal conflictmanagement mode in the ways of governing, settlement, waning or the resolution of conflict communicative processes.

Arab World English Journal for Translation \& Literary Studies 
AWEJ for Translation \& Literary Studies Volume, 4 Number 2 May 2020

Multimodal Conflict Management in English Fictional

Sieriakova, Chernenko \&Muntian

Finally, the article proposes the application of a theoretical model of multimodal discourse analysis that underpin conflict discourse studies revaluing the role and influence of nonverbal mode in conflict discourse organization, interpretation, and management.

\section{Theoretical Background of the Research}

Different approaches to the analysis of nonverbal means of communication in modern studies are characterized by cultural and psycholinguistic aspects research of nonverbal communication (Kurylo \& Rozman, 2017), functional aspects of the speaker's tactile behavior in the English fictional discourse (Zhukovska, 2018), the study of nonverbal means of expressing empathy in English dialogical discourse (Kozyarevych, 2006), nonverbal aspects of the speaker's invective behavior in conflict discourse (Zolotarenko, 2015), gender peculiarities of haptic communication (Hertenstein \& Keltner, 2011), pragmatic functions of gestures research (Kendon, 2018), the problem of using facial cues continuous speech (Mitchel \& Weiss, 2014), the analysis of nonverbal communication in the fields of security and justice (Denault et al., 2020), the character's emotional response in English fictional discourse (Netrebina, 2016), etc. Nonverbal means of communication are generally classified according to the place of their realization: for instance, kinesics as a special semiotic resource, representing kinetic modality includes gestures, facial signals, smile, and eye contact. Haptics as a particular type of sensory modality presupposes a tactile communication mode. Paralanguage is a kind of nonverbal communication based on the voice characteristics, and proxemics implies the use of the space in conversation (Argyle, 1972; Knapp \& Hall, 1997; Krejdlin, 2002). The multimodal dimension of written and oral discourses has not been studied yet in the framework of conflict discourse studies. Nevertheless, the progress in the field of nonverbal semiotics, discourse studies, linguistics of emotion, socio, and psycholinguistic can not be underestimated today, serving the background of our research.

The objective of this article is to complete a theoretical multimodal framework of conflict discourse studies by revealing structural and functional peculiarities of nonverbal conflictmanagement mode in English fictional discourse. It is achieved by fulfilling the following tasks: (i) to outline the role and functional value of nonverbal mode as a unique semiotic resource in the multidimensional space of conflict communication, (ii) to establish a peculiar correlation of verbal and nonverbal modes in conflict settlement and resolution phase, (iii) to reveal structural, semantic and pragmatic peculiarities and behavioral patterns of the use of nonverbal means of conflict communication in English fictional discourse.

\section{Methods and Material}

To achieve the objective of the research and accomplish its tasks, several general scientific methods, such as induction and deduction, analysis, and synthesis, as well as methods of linguistic analysis, such as multimodal discourse analysis, contextual and pragmatic analysis are used.

The research material includes discursive fragments, singled out from fictional discourse, with a specific focus on the designation of the characters' nonverbal behavior in everyday communicative situations of conflict interaction, predominantly selected from the works of British and American authors of the 20th-21st century (a total volume of about 2000 pages). For instance,

Arab World English Journal for Translation \& Literary Studies 
AWEJ for Translation \& Literary Studies Volume, 4 Number 2 May 2020

Multimodal Conflict Management in English Fictional

Sieriakova, Chernenko \&Muntian

the following fragment, "The doctor slapped the table in disgust. His eyes were scornful. "We're talking, "James shouted furiously, all patience gone, "about my cousin's wife!" His hands clenched fiercely" (Cabot, 2002, p. 172), illustrates the power of nonverbal mode in the development of conflict communicative situations between the characters, strengthening the verbal module, and revealing pragmatic and psychological behavioral patterns in the framework of conflict interaction.

\section{Results and Discussion}

Nonverbal means of communication play an essential role in the process of conflict interaction. They are characterized by high informative value amongst other extra-linguistic factors, influencing the process of conflict management. Since more than $60 \%$ of information has been carried nonverbally (Knapp \& Hall, 1997), nonverbal signs not only help to regulate the language system, cueing priority among communicators but provide meta-communication and feedback. Such semiotic resource, as nonverbal conflict-management mode, sometimes acts more efficiently than verbal means but as a rule in complementary redundancy to the discourse flow.

According to Arola, Ball and Sheppard (2014), the chart of the five modes of communication, based on a diagram created by the New London Group includes visual, linguistic (verbal), spatial, aural, and gestural means of communicating (Arola et al., 2014). The structural composition of nonverbal mode as a useful tool of conflict settlement and resolution comprises a wide range of nonverbal means of communication classified according to the place of their realization. Haptics is a tactile communication mode, paralanguage is a kind of nonverbal communication based on the voice characteristics. Kinesics includes gestures, facial signals, smile, eye contact; proxemics is the use of the space in communication and others (Argyle, 1972; Knapp \& Hall, 1997; Krejdlin, 2002).

Having analyzed many conflict discursive fragments, we conclude that the most frequently used type of sensory modalities, through which the multimodal phenomenon of conflict communication is realized, is kinesics including gestures, postures, various facial expressions of the characters. Facial expression and gaze serve as an explicit means of the character's internal state expression which comprises experiencing a "hostility triad" emotions, such as anger, disgust, and contempt, e. g., "She can't tell me what to do, she's not my bloody mother!..." yelled Robin. Eyes blazing and tears running down her cheeks, taking plenty of mascara with them, Robin ran from the kitchen, sobbing loudly. They heard the door to her bedroom shut (Kelly, 1998, p. 58).

The multimodal field of the fragment mentioned above, covers a specific set of sensory modalities such as auditory modality, visual modality, and kinetic modality.

Here is another example, demonstrating the intensity of gaze interaction "I'm not about to invade your father's privacy, Fred," Marta said. She spoke calmly, but the fire in her dark eyes gave her away (Charles, 1989, p. 192).

The most common lexical means of verbalization the effects of facial expression and gaze interaction in conflict discourse are: to gaze at somebody, to give a long look, to close one's eyes for a moment, to raise one's eyes, with a final glare, his eyes blazing, his eyes dropped, an ugly

Arab World English Journal for Translation \& Literary Studies 
AWEJ for Translation \& Literary Studies Volume, 4 Number 2 May 2020

Multimodal Conflict Management in English Fictional

Sieriakova, Chernenko \&Muntian

look on his face, eyes, filled with tears, eyes, sparkled, with haggard eyes, etc. (Delinsky, 2003, pp. $152-155)$.

As reported by Ekman and Friesen (1969), there are five general functions of nonverbal means of communication, constituting the nonverbal mode: repetition, contradiction, complementation, accent, and regulation. The pragmatic potential of nonverbal conflictmanagement mode is realized through completing, emphasizing, and governing, regulating verbal messages, neutralizing at the same time the illocutive polysemy of words, revealing accurate interpretation of the speaker's intentions, feelings, and emotions between the characters, e.g. She turned to face him. "Ok. That would be lovely. "

"I do love you, Dee," he said gently, tracing the contours of her cheek with one hand. He looked tired, she realized with a jolt. There were shadows under his eyes, and he'd been stifling yawns all evening.

"I know it's difficult having Mum to dinner, but I feel so guilty when she rings, and I say she can't come over," he said. "You'd want to do the same if your mother was in the same position, wouldn't you?"

"Yes," said Dee, relenting (Kelly, 1998, p. 74).

This conflict discourse fragment demonstrates a unique peacebuilding role of touch, constituting the nonverbal conflict-management mode in the conflict resolution phase. It is used to soften the verbal message in conflict, and together with proxemics, the use of the space in communication determines how comfortable communicants may get out of conflict situations. The most common lexical means of verbalization of the effects of haptic interaction in conflict are: to shake somebody by the hand, to take somebody fiercely in his arms, to gently strike somebody's hair, to touch somebody's hand gently, etc.

Contrary to the amicable role and function of touching behavior in conflict fiction discourse, the language of gestures serves as a way to demonstrate protest, unwillingness to develop the process of conflict communication, to express the emotional states of the conflicting parties during the conflict resolution phase, e.g., "You might let me know where I stand, at least."

"I won 't", said Carrie, feeling no refuge but in anger.

"You can go to the deuce as far as I am concerned", he said as he reached the door. "I'm no sucker", and with that, he opened it with a jerk and closed it equally vigorously (Dreiser, 2008, p. 201).

The most common lexical means of verbalization the gestural mode in conflict fictional discourse are: to make a dismissive gesture, she started a little, a shiver passed through her, and out he strode, and quietly closed the door of her room, with an angry gesture, gravely, to slam the door, etc. The pragmatic value of gestures is realized through the functions of completing, substituting, emphasizing, and governing the language mode.

Arab World English Journal for Translation \& Literary Studies 
AWEJ for Translation \& Literary Studies Volume, 4 Number 2 May 2020

Multimodal Conflict Management in English Fictional

Sieriakova, Chernenko \&Muntian

The use of proxemics and haptic nonverbal mode between the characters may also witness about estrangement, incomprehension, even in case of an apparent peaceful solution of conflict, e. g., "Bring Strickland here, Dirk. I'll do my best for him. "

"My precious," he smiled. He wanted to take her in his arms, but she avoided him.

"Don't be affectionate before strangers, Dirk, "she said." It makes me feel such a fool. "

Her manner was quite normal again, and no one could have told that so shortly before she had been shaken by such a great emotion (Maugham, 1972, p. 106).

Among the exclusive nonverbal cues influencing the development of conflict communication, the communicative act of silence ("--" verbal behavior, "+" nonverbal behavior) serves as a hugely informative one (Gamble \& Gamble, 2012). Furthermore, it is used as a pragmatic marker, which determines the stalemate as a peak of the conflict, its maturity, leading to resolving or waning of the conflict situation, e.g., A dead silence followed the outburst. In its midst, Griffin caught the smallest movement in the corner of his eye. Glancing back at the door, he saw Poppy. Her eyes were on Micah. She looked devastated. Griffin let out a breath. "No, I don't suppose it does," he said quietly. He glanced at Poppy again, but she continued to look at Micah. Discouraged, he said, "I've done enough for today, I guess," and let himself out the back door (Delinsky, 2003, pp. 179 - 180).

The most common lexical means of verbalization of the communicative act of silence in conflict situations in English fictional discourse are: a dead silence followed, for a moment neither man spoke, a short silence followed, for a minute a peculiar silence filled the chamber, the silence of the studio seemed to gather the body etc.

Vocal paralanguage characteristics, such as intensity, timbre, the pitch of voice, intonation, speech rate, and others help to provide a verbal message with informative, modal, emotional, evaluative, and other characteristics to complete or strengthen the verbal mode in conflict fiction discourse, e. g., She gaped at him, and then suddenly she shrilled: sacked..."

"No, you don't. I said it first. You're sacked, that's what you are - sacked, sacked,

The outburst was loud, hysterical, degrading. And at the height of it, there was an interruption (Cronin, 1963, p. 111).

As the analysis of conflict discourse fragments show, prosodic characteristics of nonverbal mode range from transmitting a smooth, quiet voice in the situation of conflict settlement (say softly, tenderly, quietly, calm, clear voice) to the expression of emotions of anger, fury, annoyance in the situation of disconnection and competing between the communicants (to say disdainfully, rudely, shortly, bitterly, in a dangerously soft voice, to yell at somebody, to shrill).

Thus, structurally, functionally, and pragmatically, the nonverbal conflict-management mode in fictional discourse may be grouped into psychological, physical, and pragmatic behavioral patterns of the character, influencing the processes of development and interpreting the conflict communicative situations in fictional discourse. By paying attention to these nonverbal

Arab World English Journal for Translation \& Literary Studies 
cues, a researcher can also detect deception or affirm the speaker's honesty in conflict interaction. Therefore, psychological patterns comprise nonverbal psychological pressure on the partner, such as threats, orders, cry, realized through the sensory modalities of posture, gaze, voice, gestures, etc., for example: "His lean hands clenched and he clicked his teeth. "Mine, mine!" he muttered, and one would have thought him a villain in a cheap melodrama. Mrs. Dale shook her head (Dreiser, 1998, p. 268). Pragmatic patterns may be explained as "nonverbal pointing" through gestures, silence, refusal, emotional suppression, etc., for e.g. Craig half hoped the noise would bring Luke running out of the house, arms raised in protest (Follett, 2005, p. 79). It should also be mentioned that behavioral patterns are closely connected with semiotic behavioral types of personality. Physical patterns presuppose the contact use of body language, gestures, such as fighting, struggle, scramble, pushing, kick, smack in the face, etc. in character' pragmatic goal achievement, for example: "You don't. You know you don't!" she flared up suddenly. "Why do you lie? You don't care. Don't touch me. Don't come to me. I'm sick of your hypocritical pretenses! Oh!" And she straightened up with her fingernails cutting into her palms. Eugene, at the first expression of disbelief on her part, had laid his hand soothingly on her arm. That was why she had jumped away from him (Dreiser, 1998, p. 304).

These behavioral patterns are closely connected and interrelated in the process of conflict development, settlement, and resolution in English fictional discourse.

As a result, these conflict-management nonverbal patterns are used by the characters to achieve different communicative intentions and to express a wide range of emotions from anger to humility. They also create some perlocutionary effect, either harmonize or disharmonize or even pseudo-harmonize the relations between conflicting parties. Moreover, those mentioned above conflict-management nonverbal behavioral patterns are often used to realize the character's goals and intentions, which are represented in the main conflict discourse strategies, influencing the beginning, escalation, culmination, and resolution of the process of conflict communication in English fictional discourse.

Accordingly, nonverbal conflict-management mode regulates, completes and even defines the choice and development of the main discourse strategies of social conflict interaction: competing, collaborating and avoiding (Hasan, 1996; Thomas \& Kilmann, 1990), e. g., "Why don't you come out and say it?" Josh suggested, his voice steel-edged.

"No."

"Then I'll say it for you. Because I'm crippled, right, and so you feel the need to protect my tender sensibilities. That's in, isn't it?"

Marta looked at him, outraged. "No," she stormed, heedless of other people in the bar. "That's not it at all. You're reading me all wrong. You've always read me all wrong, damn it!"

Marta grabbed her handbag and slid out of the banquette in one swift motion (Charles, 1989, p. 129).

In the fragment of conflict interaction in the fictional discourse, the nonverbal conflictmanagement mode performs a complementary function in realizing the competing discourse 
AWEJ for Translation \& Literary Studies Volume, 4 Number 2 May 2020

Multimodal Conflict Management in English Fictional

Sieriakova, Chernenko \&Muntian

strategy, which ends in the disconnection of conflicting parties and results in disharmonization of interpersonal relations.

\section{Conclusion}

The nonverbal conflict-management mode as a constituent part in realizing the phenomenon of multimodality in conflict discourse plays an essential role in exploring, analyzing, and interpreting conflict communicative situations. The high informative value of nonverbal mode in conflict discourse made it possible to analyze the total impact of messages transmitted nonverbally, from the viewpoint of their structural, functional, and pragmatic value. The analysis of the nonverbal mode in conflict communicative situation in English fictional discourse reveals that it is viewed as a complex of its functional, pragmatic, psychological, social, and behavioral characteristics. Therefore, in conflict communicative framework, the nonverbal conflict-management mode is represented by a set of behavioral patterns, realizing the main conflict strategies in fictional discourse. Finally, the paper has shown that such nonverbal behavioral patterns realized through a particular set of sensory modalities may influence and even regulate the process of conflict management and resolution. Multimodal discourse analysis as a study of different semiotic resources in fictional and non-fictional types of discourse may serve as an important practical tool for the development of literary and translation studies and outlines the perspectives of further research in the fields of cross-cultural, conflict-management, gender studies.

\section{About the Authors}

Iryna Sieriakova, DSc. in Philology, Professor of Linguistics at the Department of Foreign Languages, Faculty of Economics and Law, former Vice-Rector for Studies and International Affairs, Kyiv National Linguistic University, Ukraine. Her research interests include discourse analysis, the pragmatics of discursive practices, non-verbal semiotics, cross-cultural studies. ORCID ID: http://orcid.org/0000-0001-6446-7070

Olha Chernenko, Ph.D. in Philology, Associate Professor at the Department of Germanic and Finno-Ugrian Philology, Faculty of Germanic Philology, Kyiv National Linguistic University, Ukraine. Her research interests are pragmatics, conflict discourse studies, non-verbal semiotics, gender studies, grammar. ORCID ID: https://orcid.org/0000-0002-0127-8915

Oleksandr Muntian, Ph.D. in Philology, Associate Professor at the Department of the Russian Language and Literature, Dean of the Faculty of Slavic Philology, Kyiv National Linguistic University, Ukraine. His research interests are the historical linguistics, Russian studies, crosscultural studies, foreign language teaching. ORCID ID: https://orcid.org/0000-0002-7004- 0249

\section{References}

Argyle, M. (1972). Nonverbal Communication in Human Social Interaction. Nonverbal Communication, 11 (3), 243 - 268.

Arola, K. L., Ball, Ch. E., \& Sheppard, J. (2014). Writer/Designer: A Guide to Making Multimodal Projects. New York: Bedford/St. Martin's.

Bowen, A. (1982). Dangerous Promise. New York: Superromance.

Cabot, P. (2002). Kiss the Bride. New York: Sonnet Books.

Arab World English Journal for Translation \& Literary Studies

ISSN: 2550-1542 | www.awej-tls.org 
AWEJ for Translation \& Literary Studies Volume, 4 Number 2 May 2020

Multimodal Conflict Management in English Fictional

Sieriakova, Chernenko \&Muntian

Charles, M. (1989). Diamond Moods. New York: Silhouette Books.

Cronin, A. (1963). The Citadel. Moscow: Foreign language publishing house.

Delinsky, B. (2003). An Accidental Woman. New York: Pocketbooks.

Denault, V. et al. (2020). The Analysis of Nonverbal Communication: The Dangers of Pseudoscience in Security and Justice Contexts. Anuario de Psicologma Jurнdica, 30(1), 1 -12 .

Dreiser, T. (1998). Genius. Moscow: Higher school publishing house.

Dreiser, T. (2008). Sister Carrie. Moscow: Higher School Publishing House.

Ekman, P., \& Friesen, W. V. (1969). The Repertoire of Nonverbal Behaviour: Categories, Origins, Usage, and Coding. Semiotica, 1, 49 - 98.

Follett, K. (2005). Whiteout. London: Macmillan publisher.

Gamble, T. K., \& Gamble, M. (2012). Communication works (1 $1^{\text {th }}$ ed.). New York: McGraw-Hill Humanities/Social Sciences/Languages.

Hasan B. I. (1996). Psychotechnics of Conflict and Conflict Competence. Krasnoyarsk: The fund of mental health.

Hertenstein, M., \& Keltner, D. (2011). Gender and the Communication of Emotion via Touch. Sex roles, 64 (1-2), $70-80$.

Kelly, C. (1998). She's the one. London: Headline.

Kendon, A. (2018). Pragmatic Functions of Gestures: Some Observations on the History of Their Study and Their Nature. Gesture, 16 (2), $157-175$.

Kozyarevych, L. V. (2006). Verbal and Nonverbal Methods of Empathy Expression in Dialogic Discourse (on the material of English prose of XX century). (Published Doctoral Thesis). Kyiv: Kyiv National Linguistic University.

Knapp, M., Hall, J. (1997). Nonverbal Communication in Human Interaction (4 ${ }^{\text {th }}$ ed.). Forth Worth: Harcourt Brace College Publishers.

Krejdlin, G. E. (2002). Nonverbal Semiotics: Body Language and Natural Language. Moscow: Novoye literaturnoye obozreniye.

Kress, G. (2010). Multimodality: A Social Semiotic Approach to Contemporary Communication. London: Routledge.

Królikowska, P. (2015). Discourse of Conflict as Political Genre. Thesis for the doctor's degree in philology. (Published Doctoral Thesis). Łódź: Uniwersytet Łódzki. Available at: http://dspace.uni.lodz.pl/xmlui/bitstream/handle/11089/11885/Doktorat_Dyskurs\%20kon fiktu\%20jako\%20gatunek\%20polityczny_Paulina\%20Kr\%C3\%B3likowska.pdf?sequenc $\mathrm{e}=1 \&$ isAllowed $=\mathrm{y}$

Kurylo, O. Y., \& Rozman, I. I. (2017). Verbal and Nonverbal Aspects of Culture of Communication. Young Scientist, 4.3 (44.3), $114-118$.

Liddicoat, A. J. (2007). An Introduction to Conversation Analysis. London: Continuum.

Makaruk, L. L. (2015). Linguistic Approaches to the Study of Multimodal Texts. M. Wojciech, \& R. Marietta (eds.), Discourse Analysis, Pragmatics and Corpus-based Studies (Vol. III, pp. 26-36). UK: Cambridge Scholars Publishing

Malki, I. (2018). Conflict Resolution Strategies in Media Discourse: The case study. International journal of social science studies, 6(5), $24-35$.

Maugham, W.S. (1972). The Moon and Sixpence. Moscow: Progress publishers.

Arab World English Journal for Translation \& Literary Studies

ISSN: 2550-1542 | www.awej-tls.org 
AWEJ for Translation \& Literary Studies Volume, 4 Number 2 May 2020

Multimodal Conflict Management in English Fictional

Sieriakova, Chernenko \&Muntian

Mitchel, A. D., \& Weiss D. J. (2014). Visual Speech Segmentation: Using Facial Cues to Locate Word Boundaries in Continuous Speech. Language and Cognitive Processes, 29 (7), 771 -780 .

Netrebina, S. P. (2016). Somaticon of the Character's Emotional Response in English Fictional Discourse. (Published Doctoral Thesis). Kyiv: Kyiv National Linguistic University.

O'Halloran, K. (ed). (2004). Multimodal Discourse Analysis: Systemic Functional Perspectives. London: Continuum.

Steel, D. (1994). The Gift. New York: A Dell Book.

Thomas, K. W., \& Kilmann, R. H. (1990). Thomas-Kilmann Conflict Mode Instrument. New York: XICOM.

Zhukovska, A. V. (2018). The Speaker's Tactile Behaviour in English Fictional Discourse: Nominative, Communicative, and Pragmatic Aspects. (Published Doctoral Thesis). Kyiv: Kyiv National Linguistic University.

Zolotarenko, T. O. (2015). Representation of the Speaker's Invective Behaviour in Conflict Discourse (A Study of the Novels by Stephen King). (Published Doctoral Thesis). Kyiv: Kyiv National Linguistic University.

Arab World English Journal for Translation \& Literary Studies 